\title{
The Generation of Anxiety and the Recovery of Self-awareness-interpreting The Sea, the Sea Based on Rollo's Existentialist Psychology
}

\author{
Zhou Xia*, Li Jing \\ School of Foreign Language, North China Electric Power University, Baoding, China \\ Email address: \\ 348947546@qq.com (Zhou Xia), 1227298982@qq.com (Li Jing) \\ ${ }^{*}$ Corresponding author
}

To cite this article:

Zhou Xia, Li Jing. The Generation of Anxiety and the Recovery of Self-awareness-interpreting The Sea, the Sea Based on Rollo's Existentialist Psychology. International Journal of Applied Linguistics and Translation. Vol. 5, No. 4, 2019, pp. 64-71. doi: 10.11648/j.ijalt.20190504.13

Received: October 7, 2019; Accepted: November 1, 2019; Published: November 8, 2019

\begin{abstract}
Rollo's existentialist psychology not only finds the reason for human anxiety but also comes up with a solution to the anxiety. Based on Rollo's existentialist psychology, this thesis applies the close reading to interpret Murdoch's novel The Sea, the Sea, and then analyze the reason why Charles, the protagonist in the novel, returns to the current and real life from the disordered life at the seaside. His boring childhood has led to his desire for material life, his individual competitiveness and the dominant values of being loved, accepted, and approved, which is presented by his later life when he was working in the theater. With the retirement of Charles from the theater, the lonely life at the seaside destroys his values and consequently causes the loss of his sense of himself, which leads to his disordered life. But Charles's experience of death and the death of other people have brought back his self-awareness. By interpreting this novel, this paper attempts to explain that the psychological reason for Charles' chaotic life is his anxiety and the reason for anxiety is the destruction of dominant values. And the recovery of self-consciousness is the key to overcoming anxiety, making him break away from the past and return to his current life. By analyzing the psychological course of the protagonist Charles, this paper tries to strengthen readers' attention to anxiety, and help them understand anxiety, so as to lead readers find ways to overcome anxiety.
\end{abstract}

Keywords: Existentialist Psychology, Disordered Life, Anxiety, The Dominant Value, Self-awareness

\section{Introduction}

Iris Murdoch (1919-1999) is a famous British novelist after the war. She is well-known for her works and philosophical ideas. She has written more than 40 works, including 26 novels and other plays and philosophic works. Her main novels include Flight from the Enchanter, The Sandcastle, The Bell, A second Head, A Fairly Honourable Defeat, The Black Prince, The Sea, the Sea, and so on. In 1978, her famous novel The Sea, and the Sea won the Man Booker Prize and therefore attracted many critics' attention. This novel shows the most prosperous period of her writing career. As Conradi argued, the novel is the most successful one among Murdoch's works, in which, to some extent, the sorrow and joy of life intertwine, so it deserves the award [1]. It adopts the first-person narration to tell a story of Charles searching for himself. When working in the theater, Charles was controlled by his will to power.
Later he left the theater to Shruff End - a cottage near the sea because he wanted to "repent of a life of egoism" [2]. However, he failed to repent his egoism and felt so anxious that he was unable to feel his existence. Finally, he returned to London and built a connection with the eternal word.

At present, the study of this novel can be divided into four classifications. Firstly, some scholars study the novel's literary characteristics and techniques of expression. For example, Peter Conradi analyzed the explicit figures' characteristics and the open ending in the novel [1]. Some scholars focus on other works' influence on the novel. According to Lindsey Tucker, the novel is affected by Shakespeare because James and Charles are both Prospero-style figures [3]. Elizabeth Dipple compared this novel with Murdoch's another work-The Unicorn [4]. Furthermore, this novel is also analyzed from different perspectives, such as feminism [5], psychoanalysis [6]. Finally, the most general study of this novel is about the 
moral philosophy. For instance, David J. Gordon pointed out that Good is related to selflessness [7].

Although critics analyze the novel from different perspectives, most of them focus on morality. The interpretation of the novel from the psychological perspective still keeps valuable. In particularity, there is no study of it from Rollo's existential psychology.

Rollo May (1909-1994) is known as the father of American existential psychology. He inherits and merges European existentialist philosophy and psychological thought, probes into the existence and the significance of presence of human beings, and creates existential analysis and psychotherapy in the United States.

Existentialist philosophers have thought about the problem of existence. The Danish philosopher, Kerkegaard, who is the pioneer of the Existentialism, has raised that the existence of human beings should be concerned, especially the extremely awful existential condition such as anxiety, restlessness, despair, and so on [8]. Heidegger differentiates the beings from the existence [8]. Sartre proposes that the existence precedes the essence. In Sartre's drama, especially the drama of situation, the connotation of the Existentialism is divided into two aspects: one is to reveal the absurd nature of the human world; the other is to reveal that the individual has the freedom to maintain the independence of his personality in the absurd world [9]."

As Rollo has inherited the existential philosophy, he also concerns people's problems of being. In the preface to a Chinese version of Rollo's Man's Search for Himself, Guo Benyu concludes that the existential psychology of Rollo is about the existence of human beings, most of which is the sense of existence [10]. The so-called sense of being is the experience of being [10]. In other words, human beings can be aware of their own presence. Rolle believes that when a person experiences his presence through the sense of being, he will find that he is living in the world. The essence of existence is being-in-the-world, which includes three dimensions of human existence: in the Umwelt; in the Mitwelt; and in the Eigenwelt [10].

Rollo concerns the plight of existence. In his work Man's Search for Himself, he states that the predicament of modern man is loneliness and anxiety. According to Rollo, anxiety is "the human being's basic reaction to a danger to his existence, or to some value he identifies with his existence" [11]. And "anxiety strikes us at the very 'core' of ourselves: it is what we feel when our existence as selves is threatened [11]." Rollo states the reason for anxiety: "since the dominant values for most people in our society are being liked, accepted and approved of, much anxiety in our day comes from the threat of not being liked, being isolated, lonely or cast off [11]." Rollo regards this dominant value as a disguise of hostility caused by individual competition.

Rollo observes the predicament of modern man from the social background. Rollo puts forward with a question: "what basic changes are occurring which make this an age of anxiety and emptiness?" [11] According to Rollo, they mainly refer to the loss of the center of values in our society and the sense of self. The former involves that two central beliefs in our modern age, "the value of individual competition" [11], and "the faith in individual reason" [11], are not fit for the modern society. For example, individual competition has aroused hostility and resentment among many people. In addition, Rollo thinks that the new central beliefs are not found to "enable us to choose our goals constructively, and thus to overcome the painful bewilderment and anxiety of not knowing which way to move" [11].

According to Rollo, the anxiety can "destroy our consciousness of ourselves" [11], and consequently makes a person lose his sense of being. The solution Rollo provides to overcome anxiety is achieving a sense of being. Based on the emphasis of the sense of existence on self-consciousness, to obtain the sense of being is tightly related to the self-consciousness. As Rollo says, "our task, then, is to strengthen our consciousness of ourselves, to find centers of strength within ourselves which will enable us to stand despite the confusion and bewilderment around us [11]."

Based on Rollo's existential psychology and close reading, this thesis aims to analyze the reason for Charles' disordered life and that for anxiety which has a destructive influence on his self-awareness. Otherwise, this thesis also tries to discuss the solution to man's anxiety. Close reading refers to the text-centered method of interpreting literary works with semantic analysis.

\section{Charles's Childhood and His Life in the Theater - The Construction of Charles's Dominant Value}

According to the novel, it is inferred that Charles is a man who lived in the twentieth century. He lived at a time when, according to Rollo, the society has serious malady. In addition, people in Charles's age face what Rollo called the dilemma of modern people-loneliness and anxiety. Furthermore, Charles' dominant value is the same as those people in the 20th century, that is, being liked, accepted and approved. In the novel, the construction of Charles' dominant value can be tracked back to his childhood.

Charles's dominant value changed in his childhood. When he was young, the Christian value was challenged by his uncle's family. Charles was born into a Christian family. As he said, "She (his mother) was a strict evangelical Christian. My father was a Christian too of course, so was I [2]." He and his father were ordered by his mother because "She was the strong one [2]." Consequently, "My father and I loved and obeyed and comforted each other in secret [2]." In a word, Charles was influenced by his Christian family, especially by his mother.

Charles lived in a puritanical family when he was a child. His mother tended to depress her desire. In Charles's family, there is no entertainment because his parents "did not want to go anywhere or do anything" [2], but wanted to "remain always in their own house and their own garden" [2]. For example, his parents never wanted to go to the theater and particularly his 
mother "positively disapproved of it" [2], because they had little money for it. Even Charles "did not go to a restaurant" [2] until after he left school because of his boring family.

In addition, Charles has an ambivalent attitude towards his father. In Charles's memory, his father was "a quiet bookish man as somehow the gentlest being I have ever encountered" [2]. Otherwise, according to Charles, his father "had a positive moral quality of gentleness" [2]. For example, his father put a spider carefully out of the window. Charles admired his father. He was his father's comrade, his reading companion. He appreciated his father: "I remember feeling in later life that no one else ever knew how good my father was [2]." However, although Charles admired his father's gentleness, he had some negative assessment of his father. For example, he said, "I do not mean he was timid, though I suppose he was timid [2]." Otherwise, he thought that his father was a loser. According to Charles, his father "was some sort of luckless failure" [2]. His father didn't have "money, status, power, fame or any of those coveted prizes whose myriad forms" [2]. In a word, although his father had some excellent qualities, Charles still thought poorly of his father.

Furthermore, Charles didn't like his mother's oppression on him and his father. In Charles's family, his mother organized his father at home. For instance, his father's disapproving of going out was partly because of his mother's objection. In other words, his father had no right in his family. This kind of oppression made his father lose his prestige for Charles. Otherwise, what his father suffered worried him because Charles was dominated by his mother too. Because of his mother's puritanical thought, he had little interest in his childhood. As Charles wrote, "I have been watching the clouds and it occurs to me that I have never done this in my life before, simply sit and watch clouds. As a child, I would have been far too anxious to 'waste time' in this way. And my mother would stop me [2]." According to these sentences, Charles couldn't do anything that he liked without his mother's permission. His mother would prohibit some activities which may be useful for relaxing. In a word, his mother intervened in Charles's life, to make his life dull.

According to the above analysis, it is inferred that Charles's family disappointed him, and he wanted a life different from that his family had. So, Charles wanted to escape from his dull family. As he said, "From the guileless simplicity of my parents' life, from the immobility and quietness of my home, I fled to the trickery and magic of art [2]." In other words, Charles didn't like his family's simple and boring life in his childhood, and then the theater gave a chance to change his life. Besides his disappointment at his family, another reason for his fleeing is that he was induced by his uncle's family because it was better than his to some extent.

Firstly, compared with his father, his uncle (Abel) was a winner. As he wrote, "It was early evident to me that my uncle (Abel) was more loved and more fortunate than my father (Adam) [2]." His uncle had money, status, power, fame, but his father failed to possess these things. While his father "worked in 'local government"" [2], and lived in an unnamed house, his uncle "became a successful barrister in Lincoln" [2] and lives in a distinguished place with a name. Otherwise, Uncle Abel married an heiress, which "had made a more 'adventurous' marriage than my father" [2]. As for status, "in the mysterious pecking-order hierarchy of life, the Abel Arrowbys ranked above the Adam Arrowbys" [2].

Secondly, his mother was not as interesting as his aunt. His aunt Estelle was "a rich pretty American girl" [2]. However, his mother was just a secretary on a farm. While his mother didn't support entertainment, his aunt Estelle had a colorful life. As Charles argued, "She certainly represented to me some general idea of America: freedom, gaiety, noise [2]." She enjoyed her life wantonly. "Where Aunt Estelle was there were laughter, jazz music, and (how shocking) alcohol [2]." For Charles, his aunt was a very charming American woman, which aroused his yearning for her life. As he said, "my aunt was for me a symbolic figure, a modern figure, even a futuristic figure, a sort of prophetic lure into my own future [2]." In other words, Charles wanted to become someone like his aunt in his future and have a lifestyle as his aunt.

The superiority of his uncle Abel and his aunt Estelle made Charles change her dominant value. He gave up the dull life of the Christian family but wanted to chase a life that is full of materials. He "could not help bitterly coveting things" [2], though sometimes he despised them because of his father's influence. Those things are what his uncle and aunt possessed, including money, status, fame, and others. Uncle Abel and Aunt Estelle were regarded as "glamorous almost godlike beings" [2] by Charles, which caused Charles to dance around them "like a pleased dog" [2]. Because of his propensity to his uncle and aunt, Charles finally became someone like his uncle-"an ordinary self-centred go-getter, an ordinary sensualist" [2]. For example, he enjoyed his life by controlling other actors and audiences in the theater.

His longing for material things of life allures him to become someone wealthy, prestigious, successful, which promotes Charles's competitive individualism, which means that he needs to overcome others to achieve his goal. According to Rollo, the individual competitiveness "makes every man the potential enemy of his neighbor", "generates much interpersonal hostility and resentment", and "increases greatly our anxiety and isolation from each other" [11]. Charles's competitiveness can be reflected by his jealousy and hostility to James. Charles regarded James as his enemy. Benefiting from his successful father and rich mother, James had plentiful material things of life. Charles envied their ponies and their wide-ranging motor cars. Even he supposed that his uncle and aunt did not invite him to join their travel, "because James vetoed it [2]." It seems that Charles regarded his cousin as roadblocks of his entering his uncle's family and his enjoying the material things of life, which may be the reason why Charles envied James.

According to Rollo, people have tried to cover the competitiveness up "by various devices-by becoming 'joiners' of all sorts of service organizations, by being good fellows, well liked by all, and so on" [2]. Similarly, Charles also tries to find way to achieve his goal of being wealthy and reputable as well as being liked, accepted, and approved. The 
latter is just the dominant value that, according to Rollo, most modern people have. That is why he chose to flee to the theater which can provide him with not only money and fame but also audience's and other actors' attention.

Charles forms his individual competitiveness after being affected by his uncle and aunt in his childhood. And he continued his individual competitiveness while he tried to follow the dominant value of being liked, accepted, and approved when he worked in the theater. In fact, they are contradictory each other. Charles admitted that he had a life of "egoism" when he was in the theater. For example, his love affair with Clement was for promoting his careers. According to Charles, Clement scarcely had any qualities he appreciated. Firstly, Clement was far older than him. As Charles wrote, "When I was twenty, she was thirty-nine [2]." Secondly, he thought poorly of Clement. He blamed her for his loss of virginity by words "Clement swooped like an eagle [2]." Otherwise, he thought she was immoral because "She always fought mercilessly for those she loved [2]." His first mistress Clement was not praised by him, but he still had a love affair with her for a long time. Why? It is because Clement was a leader for Charles in the theater. He admitted that "she made me [2]." The example of Clement shows that Charles managed to succeed by making use of others.

Then his attitude toward audiences and other actors can illustrate his dominant value: be liked, accepted, and approved.

"The theater is an attack on mankind carried on by magic: to victimize an audience every night, to make them laugh and cry and suffer and miss their train [2]."

According to the above sentences, Charles thought that the relationship between the theater and audiences was hostile. The theater tried to victimize audiences and control their emotions. However, this is not the final aim of the theater. This attack is "partly because the audience is also a court against which there is no appeal" [2]. That is to say, the theater's attack on audiences is to draw their attention. And Charles catered to this aim and then became a director with "the assault, the noise, the characteristic impatience" [2]. By such means, Charles deemed that he was well-known: "My kind of fame not very long, but long enough" [2].

Moreover, Charles became a dictator who treated other actors ruthlessly: making them sad and nervous. The reason why he did so was that he thought "Actors expected tears and nervous prostration when I was around [2]." Even, in his opinion, other actors were masochists, and therefore, they loved such treatment. So his attack on others aimed to draw other people's attention, to get his power at the theater, and to foster his reputation, which is just in accordance with his value of being be liked, accepted, and approved.

\section{Charles Disordered Life in the Shruff End - The Generation of Charles's Anxiety}

Charles' value is the center of his life. According to Rollo, "if such a value is destroyed, the person will feel that his existence as a self has also been destroyed [11]." Rollo explained the reason for anxiety: "The great bulk of our anxiety comes when some value we hold essential to our existence as selves is threatened [11]." Rollo states the reason in more detail, "Since the dominant values for most people in our society are being liked, accepted and approved of, much anxiety in our day comes from the threat of not being liked, being isolated, lonely or cast off [11]." Therefore, when Charles's dominant value is to become someone who is liked, accepted, and approved, Charles's anxiety stems from the threat of not being hated, isolated, lonely, or abandoned. When Charles worked as a director in the theater, he thought that he was popular because of his way to communicate with others - being violent and ruthless. However, this popularity is just his fantasy. When he left the theater to the Shruff End, he suffered his little contact with others, his mistresses' blame, local people's indifference, which just caused the threat of being hated, isolated, lonely, or abandoned.

When Charles came to the Shruff End, he seldom contacted with his friends. He didn't have a telephone, so he couldn't call his friends and he only communicated by letter. Even because the postman left the letters in the dog kennel, he did not receive a letter for a long time. He began to look forward to friends' letter and asked the post office where his letters were, though he thought it would be "losing face with myself" [2]. When Charles asked himself: "Why should I now need letters or miss them or pine for them or to be surprised if nobody wrote to me" [2], he felt isolated loneliness and expressed his desire for friends and their attention. His longing for friends and their attention can be demonstrated by his letter to Lizzie who he didn't love. He sent an ambiguous letter to Lizzie in order to let her come to him because of "some fear of loneliness and death which has come to me out of the sea" [2]. But Lizzie turned him down. In a word, Charles experienced isolation and loneliness at the Shruff End.

Based on Lizzie's reply, she blamed Charles for his ruthlessness. She considered that she had been in hell when having a love affair with Charles. As Lizzie said, "You don't respect people as people, you don't see them, you're not really a teacher, you're a sort of rapacious magician [2]." Actually, Charles didn't respect people as people because he often compared his lovers and friends to animals. According to Liu Xiaohua, Charles usually described those people that he disgusted as ugly, ferocious, cunning, or powerful animals to express his psychological or verbal revenge or abuse against others [12]. For example, he compared his first mistress to an eagle, which made him lose her virginity. Another mistress Rosina was compared to beast and tiger by Charles. Moreover, Peregrine, whose wife was robbed by Charles, was regarded as bears. In short, Charles actually harmed others. But he took no account of his threat to others though he knew it. He regarded himself as the center of others and tried to dominate others. Lizzie's accusing him of ruthlessness and refusing his invitation to the Shruff End, however, broke his fantasies that he was liked by others.

Otherwise, Rosina not only criticized Charles but also 
retaliated him. Rosina revealed that "It's so easy to frighten people, to bewilder them and persecute them and terrify them out of their wits and make their lives a misery. No wonder dictators flourished [2]." Charles was just such a dictator. $\mathrm{He}$ destroyed Rosina's marriage by alluring her in order to get her, but finally abandoned her and had a love affair with another woman. So when Charles wanted to have a peaceful seaside life, she came to the Shruff End to break his peace. She blamed Charles for breaking his promise that if he had a marriage, the bride would be her. For getting back at his indifference, Rosina sneaked into his house and broke his vase and the mirror to keep him haunted. Even she wanted to hang up "turnip lantern" [2], and dress up in sheets to disguise herself as a ghost, which aimed to frighten Charles.

Charles also suffered local people's indifference when living by the sea. As he wrote, "The bar there falls silent when I enter and burst into raucous chatter when I leave [2]." The locals appeared not to welcome him and responded with silence. Charles felt their "mild hostility" [2] though they may know that he was "a famous director" [2]. He speculated that the reason why people in the bar did not warmly welcome him was that he was perhaps "something "unreal"" [2] for them. However, from Rosina's point of view, it doesn't seem to be this way:

"Well, he may not have recognized you. You aren't all that famous. I'm far more famous than you [2]."

According to Rosina - the perspective of the other, the reason why Charles was not accepted by local people may be that he was not famous enough to be recognized by them. Rosina let him realize the truth that he was not well-known as he thought, which broke his fantasy that he had been always accepted and liked by people around him because of his status of being a famous director.

In a word, Charles's lack of connection with others, his mistress's obedience to him and local people's admiration destroyed his dominant value. As Weese argued, Charles was restrained by his strategy and restricted by his illusion of power when he lived at the theater [13]. However, after he came to the seaside, what he experienced broke her self-centered thought. According to Rollo, one of the reasons for human's anxiety is the destruction of the dominant value [11]. So others' indifferent attitudes toward Charles caused his anxiety.

Charles' anxiety had a negative impact on him. As Rollo said, "Anxiety, like a torpedo, strikes underneath at the deepest level, or 'core,' of ourselves, and it is on this level that we experience ourselves as persons, as subjects who can act in a world of objects. Thus anxiety in greater or lesser degree tends to destroy our consciousness of ourselves [11]." That is to say, Charles's consciousness of himself had the risk of disappearance because of his anxiety. Then the lack of self-awareness brought Charles many problems. According to Rollo, anxiety will "disorients him, wiping out temporarily his clear knowledge of what and who he is, and blurring his view of reality around him" [11]. Next, this thesis will analyze several consequences caused by Charles's anxiety.

Firstly, Charles was haunted by the illusion of sea monster because of anxiety. In the novel, when Charles found that Rosina broke his vase and the mirror to create an atmosphere of terror, his fantasy appeared. He was staring at Rosina and then saw that "as if her face vanished, became a hole" [2] and caught sight of "snake-like head and teeth and pink opening mouth of my sea monster" [2] through the hole. For Charles, Rosina seemed to become something "unreal", which was related to the sea monster. In a word, Charles has confounded the reality and the illusion. Therefore, he can't make clear what the things around him were. That is to say, his consciousness of himself was disappearing.

Secondly, anxiety results in the loss of self-identity, which is reflected by a lack of his "sense of relatedness to nature" [11]. As Rollo said, "People who have lost the sense of their identity as selves also tend to lose their sense of relatedness to nature [11]." He provided an example that while others may think that the sea is solemn and awesome, those losing their sense of relatedness to nature will feel nothing at all when they stand on rocks at the seashore. Charles hardly had a real feeling of nature. For example, he didn't recognize the danger of the sea. He swam in the sea and thought that he was a good swimmer. "I am a skilful fearless swimmer and I am not afraid of rough water [2]." However, the sea showed his power. When he was pushed into the sea by Peregrine, the sea brought him a threat of death. He wrote, "Hands, feet, muscles, all the familiar protective mechanisms of the body are suddenly useless [2]." "No swimming could take place in that vortex [2]." Charles failed to not only recognize the power of nature but also establish an emotional contact with the plant. He wrote: "things seen which might have given pleasure, but could not [2]." In other words, he was indulged in his inner world and couldn't be alleviated by nature. According to the above example, Charles had little effective communication with nature though he was surrounded by nature. Rollo pointed out the reason for the loss of the sense of relatedness to nature: "Our relation to nature tends to be destroyed not only by our emptiness but also by our anxiety [11]."

Finally, Charles had wrong views of himself and others, especially Hartley. Charles thought that Hartley was the only woman he loved and denied his love to Clement, Rosina and Lizzie (all of these four women ever had love affairs with Charles). However, his love for Hartley is not real and what he loved is only the false Hartley. On the one hand, he described the real ugly Hartley as the hysterical bitch. On the other hand, he claimed that he loved her so much. It was clear that his description revealed a dislike of the real Hartley. When Charles met Hartley by the sea, Hartley's appearance he described was so old and unattractive. She was "a stout elderly woman in a shapeless brown tent-like dress" [2]. Her face was "haggard and curiously soft and dry" [2]. And he even accused Hartley of trampling on his purity as the jealous demon did. Therefore, it can be inferred that Charles did not have a clear understanding of his feelings and consciousness by analyzing the paradox of his language. The lack of the awareness of himself made Charles hurt others. His fantasy of loving Hartley caused him imprisoning Hartley and nearly made her crazy. Charles's love for her not only brought her enormous 
damage, but also led to Titus's death because Charles indulged Titus's swimming for being deliberately close to her son Titus.

Also, his view of Hartley's marriage was also wrong. On the one hand, he wanted Harley. On the other hand, he wanted to keep moral. He knew that if he wanted to possess Harley, he will break the marriage of Harley, which may violate the morality of Christianity. So he wanted to be a savior by belittling her husband. As he questioned, "Is her husband, Fitch, Ben whatever his name is, a jealous tyrant, is he the cause of her unhappiness?" [2] Otherwise, he tried his best to verify this point. By regarding Ben as a tyrant, Charles tried to deny Hartley's marriage and her love for her husband. However, the fact is that Ben was not a tyrant because it was Ben who took back Hartley without violence and provided her with a peaceful life. And she actually loved her husband because she finally chose to go abroad with her husband and escaped from Charles.

In a word, Charles anxiety made him lose the real feeling of nature, himself and others and then made his life disordered. But how people can overcome their anxiety? Rollo gave us an answer: "just as anxiety destroys our self-awareness, so awareness of ourselves can destroy anxiety [11]." In other words, the solution for Charles to overcome his anxiety is to strengthen awareness of himself, which will be discussed in the next part.

\section{Death's Influence on Charles - The Recovery of His Self-Awareness}

In the above paragraphs, it was mentioned that Charles lost the consciousness of himself because of anxiety. However, when Charles suffered his own death and other people's death, his consciousness of himself returned.

Charles obtained freedom and the sense of responsibility from his experience of death. "Freedom is the other side of consciousness of self" [11], which is "man's capacity to take a hand in his own development" [11]. According to Rollo, the primary step for obtaining freedom is "choosing one's self" [11], which is equal to affirming "one's responsibility for one's self and one's existence" [11]. For Charles, he achieved freedom when he got the sense of responsibility from his death and Titus's death. He was pushed into the sea by the Peregrine because Charles robbed of his wife, which made Charles feel guilty. As Duan Daoyu\& He Ning said, "Charles grasped himself in his experience with death [14]." Charles realized the fragility of his own body and his mortality. After this death experience, he jumped into the sea to swim again. However, what he did was not that he "wished to die or through that I (he) might drown" [2], but that he "swam about feeling the loneliness of the sea and that particular sensation" which he "identified as a sense of death" [2]. However, although he felt the mortality and the sense of death, he still chose to be alive, which was just responsible for himself. Moreover, the mortality and the sense of death caused the "awareness of life" and "sense of responsibility" [11]. For example, Charles realized that he had some responsibility for Titus's death. He realized that he should remind Titus of the danger of the sea which local people have told him and shouldn't have taken him diving the first day. He admitted that "my vanity had killed Titus" [2]. Possessing responsibility for others, he learned that "One can live quietly and try to do tiny things and harm no one [2]." In a word, he achieved freedom when he chose his own existence and responsibility. According to Rollo, the weaker one's self-awareness is, the less free he was [11]. On the contrary, when Charles obtained freedom and responsibility, he had more self-awareness.

Charles's self-awareness is also presented by his contact with nature when he was affected by James's death. When Charles was caught in the anxiety, he had little sense of relatedness to nature. However, after James's death, Charles could perceive nature. James's death made Charles "abandon egocentrism" [15]. For example, he started to review himself, such as his vanity. Consequently, "When Charles understood himself, he began to realize the world around him [14]." Therefore, he finally saw the sky and the sea. He saw "stars behind stars behind stars" [2] when "curtain after curtain of gauze was quietly removed" [2]. And he perceived that "the vast soft interior of the universe which was slowly and gently turning itself inside out" [2] Otherwise, he saw four seals which he had been looking for. According to Conradi, Charles's seeing the universe and the seals shows that he had come out of the world of self-projection and began to succumb to the concrete things in the world [1]. According to Rollo's existentialist therapy, psychotherapists promote patients' intention to produce the consciousness of himself on the basis of awareness [11]. For example, when they experience a blue sky at the awareness level, they realize that they are people living in such a world. In other words, one's awareness of nature will strengthen the consciousness of himself and the sense of being. Therefore, Charles's awareness of the nature is a sign of self-awareness.

The recovery of self-awareness made Charles realize "the transcender of time" [2], namely considering his present life. Rollo thought that part of the reasons for anxiety also come from the sadness of time. If people do not have the ability to set time, people may lose themselves in front of time [16]." This novel is a mix of Charles diary and memoirs, including three parts: History, Prehistory, and Postscript: Life Goes On. In the part of History, Charles not only recorded his life by the sea but also wrote down his memory of childhood and life in the theater. And the second part is entirely a memoir (about his life at the seaside) written by Charles after he returned to London. So these two parts show that Charles was immersed in the past and consequently lost himself. As Charles said that "Time had suffered a profound disturbance, and I could feel all sort of dark debris from the far past shifting and beginning to move up towards the surface [2]." Roll argued that "Thinking of the past can, of course, have the same escape function as thinking of the future [11]." In other words, Charles was escaping from his present life by recalling the past. Only in the last part of the novel-Postscript: Life Goes On, Charles started to consider his present life rather than continually reviewed the past as he did before. He finally realized that "The past 
buries the past and must end in silence, but it can be a conscientious silence that rests open-eyed [2]." That is to say, he was not indulged in the past and made use of the influence of the past on his present life to strengthen his consciousness of himself. For example, he was aware of his selflessness in his past life and wanted to do something good now. In the novel, Charles finally had reflected on himself: "I have battered destructively and in vain upon the mystery of someone else's life and must cease at last [2]." Even, he had a clear aim for his life. As he said, "One can live quietly and try to do tiny good things and harm no one [2]." According to Rollo, only when a person has a strong self-awareness, he will learn how to live in the present reality [11].

\section{Conclusion}

Based on Rollo's existentialist psychology, this thesis discusses Charles's psychological travel from being caught in the past to emphasizing the present life and from experiencing the anxiety to strengthening his self-awareness. In Charles childhood, the contrast between the boring life of Charles's Christian family and the interesting material life of his uncle's family leads to his desire for material life, which inspired his value of being liked, accepted, and approved. However, when he retired from the theater and came to the Shruff End, he confronted his little contact with others, his mistress' blame, local people's indifference, which destroyed his value that is one's core. Hence, Charles felt anxious, which made him lose the real feeling of nature, himself and others and consequently have a disordered life. For example, he imprisoned Hartley. It is lucky that Charles finally overcame his own anxiety. In the novel, Charles's experience of death, Titus's death, and James's death made Charles regain the consciousness of himself. Finally, he stopped indulging in the past and returned to the real, rational, and current life.

According to the above analysis, it is concluded that Charles's disordered life stems from his anxiety that is originated from the destruction of his dominant value, and the solution to anxiety is to strengthen his self-awareness. As Rollo said, "The stronger our consciousness of ourselves, the more we can take a stand against and overcome anxiety [11]." Otherwise, according to Charles psychological process, this thesis can draw some conclusions:

Firstly, the surrounding environment will have a great impact on the psychological state of the individual. And the formation of the dominant values of modern people can not be separated from the social environment. Secondly, the dominant values will be affected by the surrounding environment, resulting in anxiety. Furthermore, anxiety can lead to the disordered life. Therefore, there may be some psychological factors behind personal immoral behaviors, which is worthy of our deep study. Thirdly, in order to overcome the negative impact of the surrounding environment on oneself, it is necessary to strengthen one's self-awareness because it has a positive impact on individual behaviors. The individual with self-awareness can avoid the illusion and think about how to live in the real world, thus correcting the unethical behaviors.

The above conclusions are of practical significance, which may enlighten people how to face the psychological plight. At present, people are also facing the dilemma of modern people Rollo stated, including loneliness and anxiety. The anxiety is particularly obvious, which is closely related to the present social environment. At present, the age of science and technology is coming and the internet is developed, both of which result in a great change in relationship among people. People has less opportunity to communicate face-to-face and consequently people are estranged from each other. In addition, people also face the unreasonable distribution of material wealth, thus promoting the individual competitiveness. These facts all lead to the growth of anxiety, which negatively affects people's emotion, behaviors and eventually the harmony and stability of the society. Rollo's solution to the anxiety of modern people is to increase self-awareness, which is also applicable to contemporary people. With self-awareness having a positive effect on individual behaviors, people need to pay attention to their self-consciousness and to work for it. Rollo puts forward the goal of personality integration, including a reinterpretation of traditional value, such as freedom, conscience, courage. This paper has explained the positive effect of the acquisition of responsibility and freedom on self-consciousness, which shows that people should take the initiative to choose one's self and take responsibility. In this paper, the methods of obtaining self-consciousness only involve freedom and responsibility. Therefore, it can be further studied.

\section{References}

[1] Conradi, P. Iris Murdoch: The Saint and the Artist [M]. Basingstoke: Macmillan, 1986.

[2] Murdoch, Iris. The Sea, The Sea [M]. London: Penguin Random House, 1999.

[3] Tucker, Lindsey. Released from Bands: Iris Murdoch's Two Prosperos in The Sea [J], The Sea. Contemporary Literature, 3 (1986): 378-395.

[4] Dipple, Elizabeth. Iris Murdoch: Work for the Spirit [M]. Chicago: University of Chicago Press, 1982.

[5] Weese, Katherine L. Feminist Uses of the Fantastic in Iris Murdoch's The Sea, The Sea [J]. Mfs Modern Fiction Studies, 3 (2001): 630-656.

[6] Arikan, Seda. There is no Such Thing as a Sexual Relationship: Lacanian Principles in Iris Murdoch's The Sea, The Sea [J]. Journal of Graduate School of Social Sciences 3 (2015): 103-126.

[7] Gordon, David J. Iris Murdoch's Comedies of Unselfing [J]. Twentieth Century Literature 1 (1990): 115-136.

[8] Liu Huishu. On Rollo May's Existential Thought [J]. Journal of Lanzhou University (Social Science), 2016, 44 (1): 68-74.

[9] Pan Qiuyang, Feng Tao. Existentialism Philosophy in Sartre's Situation Drama [J], Academic Exchange, 2018, (2): 171-174. 
[10] May, Rollo. Man's Search for Himself [M]. Guo Benyu\& Fanghong translated. Beijing: China Renmin University Press, 2013.

[11] May, Rollo. Man's Search for Himself [M]. London: W. W. Norton \& Company, 2009.

[12] Liu Xiaohua, Hening. The Natural Writing In Iris Murdoch's Novel The Sea, the Sea [J]. Journal of Yangtze University (Social Science), 2014, 37 (03): 47-50+78.

[13] Weese, K. Feminist Uses of The Fantastic in Iris Murdoch's
The Sea, The sea $[\mathrm{J}]$. Modern Fiction Studies, 2001 (3): 630-656.

[14] Duan Daoyu. From Falling Prey to Being in Freedom - The Sea the Sea and Heideggerian's View of Truth [J]. Xian: Foreign Language Education, 2017, 38 (6).

[15] Gordon, D. Iris Murdoch's Comedies of Unselfing [J]. Twentieth Century Literature, 1990 (2): 115-136.

[16] Xing Zhanjun. The Loss and Return of Self-consciousness [J]. Theory Journal, 1998, (6): 76-80. 